\title{
Konstruk Religi dalam Sudut Pandang Mustafa Bisri di Era 4.0 Sesuai Pendekatan Semiotika Budaya
}

\author{
Mclean $\mathrm{HY}^{1}$, Zuriyati ${ }^{1}$, Saifur Rohman ${ }^{1}$ \\ ${ }^{1}$ Program studi Ilmu Pendidikan Bahasa, Pascasarjana, Universitas Negeri Jakarta, \\ Jl. Rawamangun Muka Raya, Jaktim, 13220
}

Penulis untuk korespondensi/E-mail: mcleanhy@gmail.com

\begin{abstract}
Abstrak - Konstruk Religi dalam Sudut Pandang Mustafa Bisri di era 4.0 Pendekatan Semiotik Budaya. Tujuan dari penelitian ini adalah membongkar makna religi dalam puisi "Selamat Tahun Baru, Kawan" terutama di era 4.0 menggunakan semiotic budaya. Metode yang digunakan adalah analisis descriptive menggunaka pisau semiotic budaya. Hasil penelitian menunjukan bahwa puisi Gus Mus fokus membahas urusan keyakinan yang menjadi identitas pada bangsa Indonesia yang dikaitkan dengan era sekarang, mengabaikan esensi dan cenderung lebih menunjukkan citra saja dengan memamerkan kegiatan beribadah disosial media agar mendapat pengakuan di kalangan sosial. Selain itu, unsur sosial-budaya yang muncul adalah sentimen sebagai parameter stabilitas sosial dan tujuan yang menjadi arah pergerakan masyarakat. Tidak ketinggalan adalah kekuasaan yang menentukan dan dominasi pada masyarakat, serta ketegangan juga bermain dengan penuturan yang paradoks. Dari penelitian ini dapat disimpulkan bahwa, puisi Gus Mus mengkritik fenomena- fenomena aktivitas sosial-budaya masyarakat Indonesia di era 4.0.
\end{abstract}

Abstract - Religious Constructions in the Viewpoint of Mustafa Bisri in the 4.0 era through a semiotic cultural approach. This study aims to dismantle the religious meaning in the poem "Selamat Tahun Baru, Kawan" especially in the 4.0 era using semiotic culture. The method used is a descriptive analysis using a cultural semiotic approach. The results showed that Gus Mus's poetry focused on discussing the beliefs that became the identity of the Indonesian people that were questioned by the current era, opposing the essence, and enhancing the image of images only by exhibiting worship activities on social media to get social recognition. Also, not socio-cultural issues that emerge are sentiments as social parameters and goals that are the direction of the community movement. Besides, the power that determines and domination in society, also settlement plays with a paradoxical narrative. It could be concluded. Gus Mus's poetry criticizes the phenomena of the socio-cultural activities of Indonesian people in the 4.0 era.

Keywords - Gus Mus Poetry, Religious Constructions, Semiotic Culture, 4.0 era

\section{PENDAHULUAN}

$\mathrm{I}$ stilah "Industrie 4.0" muncul sejak lama sebelum diangkat kembali di Hannover Fair tahun 2011. Revolusi ini didesain untuk menghasilkan dunia dengan "pabrik cerdas yang supertangkas" di dalamnya bukan sekadar pabrik produktif. Lewat Internet untuk segala (Internet of Things atau IoT), sistem siber-fisik berkomunikasi dan bekerja sama, selain dengan manusia, juga sangat dimungkinkan terjadi di antara sesama varian internet, secara bersamaan. Di era ini, tawaran pada sastra bukan lagi sekadar kolaborasi dan alih wahana sebab tawaran itu sudah disambut dengan baik di era sebelumnya dan tentu saja terus produktif hingga saat ini.

Salah satu contoh tindakan dalam melestarikan nilai nilai peradaban yaitu melalui puisi. Puisi sebagai salah satu bentuk karya sastra yang sebagai sarana penyampaian kritik terhadap kondisi perubahan budaya masyarakat yang sedang terjadi.

Saat ini keadaan masyrakat, umumnya sudah mulai timbul permasalahan yang sebab musababnya berasal dari kurangnya nilai nilai religi yang dimiliki. Secara tidak langsung nilai religi merupakan nilai hidup manusia yang dimaknai 
sebagai rasa kebersamaan yang menyatu pada sesuatu yang tidak dapat terlihat. Nilai nilai religi inilah yang secara tidak langsung memiliki keterkaitan dengan perkembangan era 4.0. Dimana era 4.0 menekankan kebersamaan seperti yang terdapat dalam nilai nilai religi.

Pada penelitian ini saya tertarik untuk membongkar makna yang terkandung dalam puisi yang ditulis oleh Mustofa Bisri atau lebih dikenal dengan Gus Mus. Peneliti ingin mengkaji makna puisi Gus Mus yang berjudul "Selamat Tahun Baru, Kawan." Mengkonstruk nilai religi dalam sebuah puisi yang dikaitkan dengan era 4.0 melalui pendekatan semiotic budaya. Hal ini bertujuan untuk menyampaikan kritik budaya yang sedang terjadi di era 4.0 seperti sekarang ini.

Dalam teorinya Roland Barthes, semiotik, atau dalam istilah Barthes semiologi, pada dasarnya hendak mempelajari bagaimana kemanusiaan (humanity) memaknai hal-hal (things). Memaknai (to sinify) dalam hal ini tidak dapat dicampuradukkan dengan mengkomunikasikan (to communicate) [1]. Secara tidak langsung Barthes berkaitan erat dengan budaya. Menurut Hall, Kajian budaya adalah sebuah kluster (atau formasi) ideide, gambaran-gambaran (images), dan praktikpraktik (practices) yang menyediakan cara-cara menyatakan, bentuk-bentuk pengetahuan, dan tindakan yang terkait dengan topic tertentu, aktivitas sosial atau tindakan institusi dalam masyarakat (Hall, 1997, dalam [2])

Hal ini berkaitan dengan penelitian yang telah dilakukan oleh Faizetul Ukhrawiyah dan Muhammad Munir [3] yang berjudul feminisme dalam sajak tukhôtibu al-marah al-mishrīyah karya bâkhisah al-bâdīyah (analisis semiotik roland barthes). Penelitian tersebut menemukan bahwa puisi tersebut mengandung banyak penanda yang mengarah pada pemikiran feminism. Feminisme adalah sebuah tantangan untuk menghadapi kesetaraan antara hak dan kewajiban untuk perempuan yang bisa direalisasikan jika ada kombinasi antara pembaratan dengan pengajaran islam dan traditional. Selanjutnya, penelitian yang dilakukan oleh Nurweni Saptawuryandari [4] Yang Berjudul Analisis Semiotik Puisi Chairil Anwar. Tujuan yang ingin dicapai dari tulisan ini adalah mengetahui makna dari teks-teks puisi Chairil Anwar. Puisi tersebut, antara lain,"Derai-Derai Cemara", "Pada Sebuah Kamar", dan "Yang Terampas dan Yang Putus". Ketiga puisi itu dianalisis secara semiotic untuk dapat diungkapkan isi dan makna dari puisi tersebut. Hasil penelitian menunjukkan bahwa puisi yang ditulis oleh Chairil Anwar mempunyai makna yang dapat dijadikan bahan bacaan dan pesan-pesan untuk diketahui oleh pembaca.

Dari penelitian yang telah dilakukan peneliti tertarik untuk menggungkap puisi ditinjau dari semiotic budaya yang kemudian dikaitkan dengan era 4.0.

\section{METODE}

Metode yang digunakan dalam penulisan artikel ini adalah penelitian deskriptif kualitatif berdasarkan kajian pustaka. Pendekatan ini diharapkan dapat memberikan gambaran secara cermat mengenai keadaan atau gejala tertentu pada objek kajian. Ebook, buku, artikel merupakan salah satu teknik dalam pengumpulan data melalui studi pustaka. Puisi berjudul "Selamat Tahun Baru, Kawan" menjadi sumber data dalam artikel ini. Teknik analisis data dilakukan dengan pendekatan semiotika budaya berdasarkan konstruk religi dalam puisi yang dikaitkan dengan era 4.0. Proses analisis data yang dilakukan mencakup reduksi data dan sajian data dengan cara menyeleksi, memfokuskan, dan menyederhanakannya. Setelah reduksi data, pada tahap sajian data akan disusun informasi yang ditemukan, lalu disajikan secara lengkap sesuai dengan kategorinya. Selanjutnya, data ini digunakan sebagai rujukan penarikan simpulan penelitan dan beberapa saran yang dianggap perlu.

\section{HASIL DAN PEMBAHASAN}

Sastra dalam persepektif cultural studies menjelaskan bahwa kebudayaan sebagai suatu keseluruhan yang terintegrasi, ketika hendak menganalisis membagi keseluruhan itu ke dalam unsur-unsur besar. Ketujuh unsur yang dapat kita sebut sebagai isi pokok dari tiap kebudayaan didunia adalah bahasa, system, pengetahuan, organisasi sosial, system peralatan hidup dan teknologi, system mata pencaharian hidup, system religi dan kesenian [5].

Penulis menganalisis puisi berjudul Selamat Tahun Baru Kawan karya Ahmad Mustafa Bisri dari perspektif konstruk religi, era 4.0 dan semiotic budaya. Puisi berjudul "Selamat Tahun Baru, Kawan" merupakan bentuk ungkapan tentang 
segala perasaan dan kegelisahaan penyair dalam memaknai tahun baru (new year). Pada puisi tersebut melibatkan bahasa sebagai simbol dan melibatkan konteks yakni sosial dan budaya yang berada di antara proses komunikasi tersebut. Pada tahapan sistem bahasa, makna yang dimunculkan bisa ditarik dari segi denotatif dan konotatif. Kemudian, permainan diksi juga dimainkan Gus Mus. Pemilihan diksi menunjukkan representasi tertentu. Selanjutnya, permainan rima dan irama juga menjadi aspek penting pada puisi Gus Mus.

Selanjutnya, dalam sistem sosial-budaya, pada puisi Gus Mus fokus membahas urusan keyakinan yang menjadi identitas pada banyak puisinya.

Dia mengkritisi cara berkeyakinan dan memaknai Islam terutama di Indonesia yang mengabaikan esensi dan cenderung lebih menunjukkan citra saja. Selain itu, unsur sosial budaya yang muncul adalah sentimen yang bisa parameter stabilitas sosial, dan tujuan yang menjadi arah pergerakan masyarakat.

Tidak ketinggalan adalah kekuasaan yang penentu dan dominasi pada masyarakat, dan ketegangan juga bermain dengan penuturan yang bersifat paradoks.

Puisi yang akan dianalisis berjudul Selamat Tahun Baru Kawan. Puisi tersebut merupakan salah satu dari buku Antologi Puisi Tadarus karya Gus Mus, yang diterbitkan oleh Adicita Karya Nusa Yogyakarta pada 2003. Berikut puisi Selamat Tahun Baru Kawan karya Mustofa Bisri (2003).

\section{Selamat Tahun Baru Kawan \\ Oleh: KH A Mustofa Bisri}

Kawan, sudah tahun baru lagi

Belum juga tibakah saatnya kita menunduk memandang diri sendiri

Bercermin firman Tuhan, sebelum kita dihisab-Nya

Kawan siapakah kita ini sebenarnya?

Muslimkah, mukminin, muttaqin,

kholifah Allah, umat Muhammadkah kita?

Khoirul ummatinkah kita?

Atau kita sama saja dengan makhluk lain atau bahkan lebih rendah lagi

Hanya budak perut dan kelamin
Iman kita kepada Allah dan yang ghaib rasanya lebih tipis dari uang kertas ribuan

Lebih pipih dari kain rok perempuan

Betapapun tersiksa, kita khusyuk didepan masa

Dan tiba tiba buas dan binal disaat sendiri bersamaNya

Syahadat kita rasanya lebih buruk dari bunyi bedug, atau pernyataan setia pegawai rendahan saja.

Kosong tak berdaya.

Shalat kita rasanya lebih buruk dari senam ibu-ibu

Lebih cepat dari pada menghirup kopi panas dan lebih ramai daripada lamunan 1000 anak pemuda.

Doa kita sesudahnya justru lebih serius memohon enak hidup di dunia dan bahagia dis urga.

Puasa kita rasanya sekadar mengubah jadual makan minum dan saat istirahat, tanpa menggeser acara buat syahwat, ketika datang rasa lapar atau haus.

Kita manggut manggut, ooh...beginikah rasanya dan kita sudah merasa memikirkan saudara saudara kita yang melarat.

Zakat kita jauh lebih berat terasa dibanding tukang becak melepas penghasilanya untuk kupon undian yang sia-sia

Kalaupun terkeluarkan, harapan pun tanpa ukuran upaya-upaya Tuhan menggantinya lipat ganda

Haji kita tak ubahnya tamasya menghibur diri, mencari pengalaman spiritual dan material, membuang uang kecil dan dosa besar.

Lalu pulang membawa label suci asli made in saudi "HAJI"

Kawan, lalu bagaimana dan seberapa lama kita bersama-Nya

atau kita justru sibuk menjalankan tugas mengatur bumi seisinya,

mensiasati dunia khalifahnya,

Kawan, tak terasa kita semakin pintar, mungkin kedudukan kita sebagai khalifah mempercepat proses kematangan kita paling tidak kita semakin pintar berdalih 
Kita perkosa alam dan lingkungan demi ilmu pengetahuan

Kita berkelahi demi menegakkan kebenaran, mengacau dan menipu demi keselamatan

Memukul, mencaci demi pendidikan

Berbuat semaunya demi kemerdekaan

Tidak berbuat apa apa demi ketenteraman

Membiarkan kemungkaran demi kedamaian pendek kata demi semua yang baik halallah sampai yang tidak baik.

Lalu bagaimana para cendekiawan, seniman, mubaligh dan kiai sebagai penyambung lidah Nabi

Jangan ganggu mereka

Para cendekiawan sedang memikirkan segalanya

Para seniman sedang merenungkan apa saja

Para mubaligh sedang sibuk berteriak kemanamana

Para kiai sibuk berfatwa dan berdoa

Para pemimpin sedang mengatur semuanya

Biarkan mereka di atas sana

Menikmati dan meratapi nasib dan persoalan mereka sendiri.

Berdasarkan penjelasan diatas, peneliti menemukan beberapa data terkait puisi yang dapat dilihat pada tabel dibawah ini.

Tabel. 1 Data Kajian Puisi

\begin{tabular}{ll}
\hline \multicolumn{1}{c}{ Data } & \multicolumn{1}{c}{ Kategori } \\
\hline Kawan siapakah kita ini & mengintropeksi \\
sebenarnya? Muslimkah, & diri sendiri \\
mukminin, muttaqin, & \\
kholifah Allah, umat & \\
Muhammadkah kita? & \\
Khoirul ummatinkah kita? & \\
Lalu bagaimana para & Peran di \\
cendekiawan, seniman, & masyarakat \\
mubaligh dan kiai sebagai & \\
penyambung lidah Nabi. & \\
Jangan ganggu mereka & \\
Kita perkosa alam dan .. & proses \\
Tidak berbuat apa apa demi & perenungan yang \\
ketenteraman & mendalam \\
Shalat kita rasanya lebih & mengkritik \\
\hline
\end{tabular}

\begin{tabular}{|c|c|}
\hline Data & Kategori \\
\hline $\begin{array}{r}\text { lamunan } 1000 \text { anak } \\
\text { pemuda. }\end{array}$ & $\begin{array}{l}\text { konsep keyakinan } \\
\text { pada diri } \\
\text { sebagian umat } \\
\text { Islam yang } \\
\text { dinilai tidak lagi } \\
\text { sesuai }\end{array}$ \\
\hline Memukul, mencaci demi & Perasaan sebagai \\
\hline $\begin{array}{c}\text { pendidikan } \\
\text { Doa kita sesudahnya justru }\end{array}$ & $\begin{array}{l}\text { Sistem sosial } \\
\text { tuiuan sebagai }\end{array}$ \\
\hline lebih serius memohon enak & sistem sosial \\
\hline $\begin{array}{l}\text { hidup di dunia dan bahagia } \\
\text { di surga }\end{array}$ & \\
\hline $\begin{array}{r}\text { Puasa kita rasanya .... kita } \\
\text { yang melarat. }\end{array}$ & $\begin{array}{l}\text { mengkritik } \\
\text { manusia dalam } \\
\text { menengakkan }\end{array}$ \\
\hline $\begin{array}{r}\text { Zakat kita jauh lebih } \\
\text {...Tuhan menggantinva lipat }\end{array}$ & rukun islam \\
\hline ganda & \\
\hline \multicolumn{2}{|l|}{$\begin{array}{r}\text { Haji kita tak ubahnya } \\
\text { tamasya menghibur diri, ..., } \\
\text { "HAJI" }\end{array}$} \\
\hline \multicolumn{2}{|l|}{ Kawan, ...khalifahnya. } \\
\hline $\begin{array}{r}\text { Para pemimpin sedang } \\
. . \text { mereka sendiri }\end{array}$ & $\begin{array}{l}\text { Kekuasaan } \\
\text { system sosial }\end{array}$ \\
\hline $\begin{array}{r}\text { Kawan, tak terasa } \\
\text { kita semakin pintar, ... } \\
\text { Halallah sampai } \\
\text { yang tidak baik. }\end{array}$ & $\begin{array}{l}\text { dua sisi yang } \\
\text { berbeda dan } \\
\text { bersifat paradoks }\end{array}$ \\
\hline
\end{tabular}

Perayaan tahun baru Masehi biasanya identik dengan terompet, petasan, dan kembang api. Tetapi tahun baru hijriah yang diperingati oleh umat Islam tidak ada pesta yang berlebihan. Penganutnya yakni umat muslim lebih memilih untuk berdoa diakhir tahun dan awal tahun di rumahnya masing-masing. Tujuannya adalah agar dosa-dosanya yang lalu bisa diampuni oleh Allah SWT dan segala keinginan/hajatnya ditahun depan bisa segera terkabulkan. Dalam pembahasan ini peneliti akan mengaitkan konstruk religi dalam puisi yang dihubungan dengan fenomena era 4.0 melalui pendekatan semiotic budaya. Pada era 4.0 manusia dihadapkan pada pencapaian individu yang memunculkan egoism, ketidakpedulian, serta diarahkan pola pikirnya pada modern kapitalisme (neoliberalisme).

Dalam puisi Gus Mus tentu tak lepas dari pandangan beragama zaman sekarang terutama 4.0. Selamat Tahun Baru, Kawan sebagai judul puisi 
yang ditulis Gus Mus juga memiliki makna yang beragam. Ucapan selamat tahun baru secara umum bersifat suka cita dan memberikan harapan baru bagi orang. Namun, setelah membaca keseluruhan puisi tersebut, justru kalimat selamat tidak mengandung ungkapan yang menyenangkan melainkan Gus Mus justru menghadirkan makna refleksi terhadap diri sendiri. Jika kita membandingkan tahun baru Masehi dan tahun baru Hijriah. Maka tahun baru Masehi akan terasa lebih meriah dibandingkan dengan tahun baru Hijriah. Kalender Masehi dihitung sejak kelahiran Nabi Isa Al-Masih (Yesus Kristus atau dalam bahasa ibrani "Yesua ha-Masiah") karena itu kalender ini dinamakan menurut Yesus atau Masihiyah (mesias). Jadi tahun baru jauh dari ajaran islam itu sendiri.

Puisi itu bermakna ajakan untuk mengintropeksi diri sendiri. Gus Mus menggunakan kalimat "kawan" yang berarti tidak adanya kesenjangan baik level sosial, umur dll. Penyair menempatkan diri nya sendiri setara dengan pembaca puisi tidak tinggi maupun rendah. Dia memposisikan diri sama dengan orang yang ingin diingatkan dan diajak merenungi makna tahun baru.

Kawan siapakah kita ini sebenarnya? Muslimkah, mukminin, muttaqin, kholifah Allah, umat Muhammadkah kita? Khoirul ummatinkah kita?

(Bisri, 2003)

Pada bait puisi di atas menunjukkan adanya penandaan struktur kebahagiaan, penguraian makna, variasi pola struktur seperti diungkapkan Pierce dalam kajian semiotika. Muslim, mukminin, dan muttaqin merupakan steorotipe dalam kepribadian seorang penganut agama Islam. Muslim adalah tingkatan dasar yakni orang yang pernah mengucapkan kalimat syahadat. Kalau mukminin adalah orang beriman dan muttaqin adalah orang yang bertakwa yang mana melaksanakan perintah dan larangan Allah. Bukan hanya itu, kholifah Allah adalah manusia sebagai pemimpin di dunia. Dari ketiga symbol makna memiliki arti yang sangat mengkritik adalah umat Nabi Muhammad. Khoirul ummatin adalah umat yang baik. Bukan hanya makna denotatif yang muncul pada diksi tersebut. Akan tetapi, juga muncul makna konotatif di dalamnya. Muslim merupakan kelompok yang pertama disebut Gus Mus, tetapi bukan mereka sebagai target utama yang disindir. Namun, khoirul ummatin yang berarti umat terbaik diantara manusia lainnya. Gus mus mengkritis bahwa apakah kita menjadi dari salah satu penerus umat Muhammad SAW yaitu Kholifah Allah atau sekedar ikut ikutan bertopeng dibalik kata islam.

Selanjutnya, kronstruk religi ditunjukkan dengan bagaimana steoritipe itu juga berlanjut pada tataran yang ada di masyarakat (budaya). Hal tersebut dikarenakan seorang Islam memiliki peran di masyarakat apakah perannya berubah seiring dengan perkembangan zaman.

Lalu bagaimana para cendekiawan, seniman, mubaligh

dan kiai sebagai penyambung lidah Nabi Jangan ganggu mereka

(Bisri, 2003)

Dari kutipan puisi di atas, menunjukkan bahwa pemilihan diksi tersebut tentunya bagaimana kategorisasi dalam orang Islam itu termanifestasikan dalam berbagai profesi yang memiliki peran di masyarakat. Mereka yang disebut Gus Mus dalam puisinya menunjukkan adanya kontribusi besar mereka bagi masyarakat. Symbol Cendekiawan, memiliki makna seseorang yang memiliki sikap hidup yang terus menerus meningkatkan kemampuan berpikirnya untuk dapat mengetahui atau memahami sesuatu. Namun, cendekiawan disini yang dimaksud adalah seseorang yang memiliki ilmu namun tidak bermanfaat pada lingkungannya. Hal ini sudah bukan hal lumrah yang kita jumpai dalam era industri ini, seseorang berilmu malah sekadar mencari keuntungan buat dirinya sendiri tanpa memikirkan efek samping terhadap sosial atau lingkungannya sehingga menciptakan manusia manusia yang egois dan tamak. Bukankah dalam islam mengajarkan ilmu akan bermanfaat apabila di sebarkan bukan dipendam sendiri.

Symbol Seniman bukan hanya representasi orang yang membuat karya yang bermutu. Seniman, bukan lagi orang yang mampu menghibur dan menciptakan kesenangan di masyarakat. Namun seniman yang dimaksud disini adalah seniman yang menghasilkan karya hanya untuk mendapat keuntunga diri mereka sendiri dan kelompok mereka, tidak bisa dinikmati masyarakat. Dalam kajian sistem bahasa, permainan rima dan irama juga dimainkan dalam puisi tersebut. Meskipun hal 
itu tidak menjadi dominan dalam puisi tersebut. Hal itu hanya sebagai selingan untuk menghadirkan estetika sehingga enak dibaca dan nyaman ketika didengarkan.

Kita perkosa alam dan lingkungan demi ilmu pengetahuan

Kita berkelahi demi menegakkan kebenaran,mengacau dan menipu demi keselamatan Memukul, mencaci demi pendidikan Berbuat semaunya demi kemerdekaan Tidak berbuat apa apa demi ketenteraman

(Bisri, 2013)

Dari kutipan puisti di atas, menunjukkan bahasa puisi bersifat unik. Salah satunya adalah penekanan pada rima dan irama saja yang dimainkan. Memang rima dan irama akan menimbulkan kesan yang berbeda ketika puisi tersebut dibaca. Rima dan irama juga bisa menjadi suatu bentuk penegasan kalau karya tersebut adalah puisi. Pasalnya, rima dan irama memang sudah menjadi hal yang identik dengan puisi. Meskipun, banyak juga penyair yang menyusun puisi tanpa memperhatikan irama dan rima.

Dalam pandangan penulis, justru puisi yang memiliki irama dan rima akan memiliki daya kekuatan yang lebih meledak ketika dibaca dibandingkan puisi yang tidak memilikinya. Bukan saja pendengar saja akan menikmati, tetapi seorang penyair yang membacakan puisi akan merasakan getaran dari efek rima dan irama. Getaran itu sendiri akan menimbulkan semangat dan menumbuhkan atmosfir yang sesuai dengan isi puisi tersebut.

Rima dan irama dalam puisi Gus Mus itu juga menunjukkan kecerdasan penyair yang menulisnya. Itu tidak hanya berkaitan dengan pemilihan diksi dengan akhiran yang sama. Jauh dari itu. Di sana ada proses perenungan yang mendalam. Termasuk di dalamnya ada makna yang saling berkaitan satu sama lain.

Dalam puisi Gus Mus terlihat sistem budaya sosial yaitu keyakinan dalam beragama. Hal ini karena melihat latar belakang Gus Mus adalah seorang ulama Nahdatul Ulama yang tak diragukan lag, hal ini terlihat dalam puisinya yang kerap bersinggungan dengan urusan keyakinan, yakni
Islam. Keyakinan memang sebenarnya bukan hanya berkaitan dengan agama semata, tetapi, kepercayaan yang bersungguh sungguh, misalnya agama, memiliki nilai yang terukur dan bersifat komunal.

Dalam puisinya, Gus Mus menyindir keras berkaitan dengan keyakinan yang secara tidak langsung menyinggung rukun islam. Dia juga mengkritik konsep keyakinan pada diri sebagian umat Islam yang dinilai tidak lagi sesuai dengan keyakinan yang sebenarnya atau keyakinan yang sekedar menyempurnakan rukun islam mereka.

Shalat kita rasanya lebih buruk dari senam ibu-ibu

\section{Lebih cepat dari pada menghirup kopi panas dan} lebih ramai daripada lamunan 1000 anak pemuda.

(Bisri, 2003)

Pabila kita melihat fenomena sekarang bahwa banyak orang solat dengan cara tergesa gesa seperti ayam yang sedang mematok, tidak menyepurnakan ruku dan sujudnya. Hal ini dikirakan banyak pandangan beragama islam yang ingin mempraktiktiskan cara beragama. Selain itu puisi diatas adalah sebuah sindiran yang sangat keras dari Gus Mus. Salat adalah amalan yang pertama dihisab di akhirat. Ukuran keimanan seorang Muslim umumnya dilihat dari salat. Apalagi, salat juga disebut sebagai tiang agama. Ketika salat saja sudah disepelekan dan dinomorduakan, maka keyakinan pun bisa keropos dan mudah digoyang.

Sebagian umat Islam tidak lagi menjadikan salat sebagai urusan penting. Mereka lebih senang dengan urusan dunia yang fana dan sementara. Padahal, urusan keyakinan bukan urusan hati saja. Urusan keyakinan terutama salat juga menjadi pijakan untuk menjadi pribadi yang lebih baik

Perasaan sentimen juga menjadi bagian dari sistem sosial. Perasaan bukan urusan pribadi semata karena masyarakat adalah mahkluk sosial. Dia tidak bisa hidup sendiri. Keberlangsungan suatu masyarakat juga ditentukan oleh perasaan yang ada di dalam hati manusia, apakah rasa suka, benci, dan lain sebagainya.

Memukul, mencaci demi pendidikan 
Manusia memiliki pikiran untuk berpikir, tetapi realitasnya digunakan untuk membiarkan keburukan/ kebatilan, dan bahkan ia sendiri menggunakan pikirannya untuk melakukan keburukan itu sendiri. Bahkan dengan berbagai macam keburukan itu, manusia sangat pandai menutupinya. Seakan-akan hal itu sebagai sesuatu yang biasa dan cepat tertutupi dengan kebaikankebaikan lain. Kemunafikan inilah, bagi penyair, harus diungkap di dalam kata-kata puisinya. Karena hal tersebut sebagai dasar untuk menyadarkan kita sebagai manusia untuk menghindari nilai ketidakmanusiaannya itu.

Selanjutnya, tujuan menjadi hal penting dalam sistem sosial. Tujuan bisa diwujudkan dalam cita cita seseorang dan cita cita masyarakat. Hal tersebut yang akan mengendalikan perasaan dan pikiran untuk kehidupan sosial yang lebih baik.

Doa kita sesudahnya justru lebih serius memohon enak hidup di dunia dan bahagia di surga.

(Bisri, 2003)

Dari kutipan puisi di atas, doa merupakan awalan pertama dalam mewujudkan target. Melalui doa, manusia akan memiliki target yang jelas. Melalui doa, orang juga akan melihat visi dan misi yang lebih jelas untuk mewujudkan citacita. Dengan doa, semangat pun bisa dipupuk sehingga langkah dan ayunan akan semakin mantap. Akan tetapi, justru cita-cita manusia hanya menginginkan kenikmatan dunia dan di surga. Mereka lebih peduli dengan hal yang menyenangkan dan membahagiakan saja. Bahkan, hanya untuk diri mereka sendiri, kelompok mereka, dan golongan mereka.

Selanjutnya, dia mengkritik manusia dalam menengakkan rukun islam yang memiliki makna. Hal ini bisa terlihat dalam bait dibait ini

Puasa kita rasanya sekadar mengubah jadual makan minum dan saat istirahat, tanpa menggeser acara buat syahwat

Ketika datang lapar atau haus, Kita manggut manggut, ooh...beginikah rasanya dan kita sudah merasa memikirkan saudarasaudara kita yang melarat.
Zakat kita jauh lebih dari berat terasa dibanding tukang becak melepas penghasilannya untuk kupon undian yang sia-sia Kalaupun terkeluarkan, harapan pun tanpa ukuran upaya-upaya Tuhan menggantinya lipat ganda

Haji kita tak ubahnya tamasya menghibur diri, mencari pengalaman spiritual dan material, membuang uang kecil dan dosa besar. Lalu pulang membawa label suci asli made in saudi, "HAJI"

Kawan, lalu bagaimana, bila mana dan berapa lama kita bersama-Nya Atau kita justru sibuk menjalankan tugas mengatur bumi seisinya, mensiasati dunia sebagai khalifahnya.

(Bisri, 2003)

Lebih lanjut dengan frasa-frasa berikutnya, penyair dengan berani mengungkapkan isi hati dengan terus menggunakan luapan-luapan kata-kata yang menyadarkan kita semua tentang apa yang selama ini kita lakukan. Apakah sudah benar kebaikankebaikan yang selama ini dilakukan sesuai dengan koridor manusia beriman atau tidak. Ritual sholat semestinya untuk perbaikan dan muhasabah diri, tetapi justru banyak digunakan sebagai aktivitas harian yang tidak memiliki implikasi apapun terhadap kehidupan. Bagitu pula puasa, zakat dan aktivitas keagamaan lainnya. Penyair dengan 'geram' mempertanyakan sudah benarkah semua aktivitas kehidupan kita selama ini. Sudah dapat nilai "A" kah perbuatan kita di mata Tuhan, atau jangan-jangan kita hanya sibuk menutupi nilai "E" tanpa berbuat apa-apa untuk memperbaikinya. Dimana fenomena sekarang yang terjadi, banyak orang sholat cuma untuk di publish dimedia sosial untuk memberitahu kepada semua orang bahwa dia beriman dan lain sebagainya yang berarti bernilai dimata manusia namun nol dimata Allah.

Selanjutnya, kekuasaan menjadi sistem sosial yang sangat lekat dengan unsur politik. Mereka yang berkuasa dalam iklim demokrasi dipilih oleh rakyat. Meski terkadang menghalalkan segala cara untuk mendapatkan kursi. Meski kekuasaan diraih dengan kezaliman. Hal tersebut terjadi karena kekuasaan menjadi magnet yang mampu memperkuat diri dan kelompoknya.

Para pemimpin sedang mengatur semuanya Biarkan mereka di atas sana 
Menikmati dan meratapi nasib dan persoalan
mereka sendiri

(Bisri, 2003)

Adapun yang kita temui sekarang ini bahwa pemimpin selalu melakukan blusukan dengan diikuti media, mereka bersembunyi dibalik media. Segala sesuatunya dinilai sebagai pencitraan tidak benar benar tulus dan bertanggung jawab.

Sebagai sistem sosial yang memiliki kekuatan, kekuasaan dalam hal ini adalah pemerintah mampu mendominasi kehidupan sosial. Mereka hadir karena mereka memiliki alat kekuasaan untuk menegakkan hukum dan aturan. Namun, kekuasaan juga memiliki tanggung jawab besar karena harus bertanggungjawab dalam hal keamanan dan kesejahteraan rakyat yang dipimpinnya. Mereka tidak bisa semena-mena karena mereka terikat dengan janji politik. Akan tetapi, seperti yang disindir Gus Mus, kekuasaan yang dipegang oleh pemimpin justru menghadapi dilema. Mereka menikmati dan meratapi. Gus Mus sepertinya ingin menggugah semua pemimpin yang terlalu sibuk mengurusi urusan sendiri, tetapi mengabaikan urusan yang lebih penting yakni rakyatnya dan mengabaikan tanggungjawabnya. Dia juga mengajak masyarakat untuk tak perlu meributkan para pemimpin yang sibuk dengan urusannya sendiri. Bukan kah, ketika kita kembali kepada sang pencipta akan diminta pertanggung jawaban atas apa yg telah kita lakukan dalam memegang kuasa.

Kemudian, ketegangan sangat bermain pada puisi Gus Mus. Dia menampilkan dua sisi yang berbeda dan bersifat paradoks. Itu menjadi fenomena kebanyakan orang di Indonesia. Hal itu sangat serius karena tidak ada manusia tidak lagi percaya dengan esensi, karena citra bisa yang ditampilkan bisa menipu. Sikap dan pemikiran tidak mencerminkan pemikiran dan perasaan. Hal tersebut dikarenakan banyak manusia mengandalkan rekayasa dalam kehidupan mereka.

Kawan, tak terasa kita semakin pintar, mungkin kedudukan kita sebagai khalifah mempercepat proses kematangan kita paling tidak kita semakin pintar berdalih Kita perkosa alam dan lingkungan demi ilmu pengetahuan

Kita berkelahi demi menegakkan kebenaran, mengacau dan menipu demi Keselamatan

Memukul, mencaci demi pendidikan

\begin{abstract}
Berbuat semaunya demi kemerdekaan Tidak berbuat apa apa demi ketenteraman Membiarkan kemungkaran demi kedamaian pendek kata demi semua yang baik Halallah sampai yang tidak baik.
\end{abstract}

(Bisri, 2003)

Dari kutipan puisi di atas, mengandung makna bahwa manusia zaman sekarang memang suka berdalih. Terkadang mereka mengetahui apa yang mereka lakukan itu salah, tetapi mereka menggunakan pengetahuan untuk mencari dalih, mencari pembenaran dengan kebutuhan masyarakat, dan mengusaha semuanya berjalan lancar dengan segala cara. Tipuan demi kepentingan pribadi pun menjadi hal biasa. Dengan dalih untuk kebutuhan dan kepentingan masyarakat. Hal ini bisa kita temui dalam situasi politik Indonesia, berdalih bahwa mereka benar namun sebenarnya mereka menyembunyikan kebenaran untuk melindungi diri mereka sendiri. Menanamkan mental tidak jujur pada diri sendiri.

Gus Mus mengkritik sebagian masyarakat yang selalu melihat segala sesuatu dari jangka pendek, bukan jangka panjang. Otak mereka lebih berpikir pendek, enggan berpikir panjang. Hal tersebut karena mereka terjebak pemikiran dan konsep yang salah tentang hidup. Gus Mus menjelaskan kalau itu semua karena orang belum mengalami "proses pematangan" yang cukup dalam keilmuan dan keprofesionalitasan. Mereka mudah dibeli oleh uang, kekuasaan, dan pengalaman. Mereka tidak mau berpijak pada moralitas dan kepentingan bersama.

\section{KESIMPULAN}

Puisi berjudul Selamat Tahun Baru Kawan merupakan bentuk kontruk religi dalam menghubungkan sastra antara Gus Mus dengan pembacanya. Sistem bahasa pada puisi karya Gus Mus tersebut memunculkan makna yang bisa ditarik dari segi denotatif dan konotatif atau semiotic budaya. Kemudian, permainan diksi juga dimainkan Gus Mus. Pemilihan diksi menunjukkan representasi tertentu. Selanjutnya, permainan rima dan irama juga menjadi aspek penting pada puisi Gus Mus.

Dalam sistem sosial-budaya, pada puisi Gus Mus fokus membahas urusan keyakinan yang menjadi identitas pada banyak puisinya. Dia menyindir cara 
berkeyakinan banyak umat Islam terutama di Indonesia yang mengabaikan esensi dan cenderung lebih menunjukkan citra saja dengan memamerkan kegiatan beribadah disosial media agar mendapat pengakuan. Selain itu, unsur sosial-budaya yang muncul adalah sentimen sebagai parameter stabilitas sosial dan tujuan yang menjadi arah pergerakan masyarakat. Tidak ketinggalan adalah kekuasaan yang menentukan dan dominasi pada masyarakat, serta ketegangan juga bermain dengan penuturan yang paradoks.

Sehingga, perlu kemantangan dalam hal pikiran menyikapi kepercayaan yang kita anut dan menentukkan arahnya apakah tulus mendapat ridho allah atau pengakuan dari sesame manusia. Terkadang kita secara tidak sadar menunjukkan kebaikan kita didepan umum agar bisa mendapatkan pujian dari sesama manusia. Namun sebenarnya nilai dari pujian itu hanya kita dapatkan di dunia. Jika dihadapan Allah SWT hal itu tidak bernilai sama sekali. Malahan hal tersebut bisa mengurangi bobot pahala yang telah kita lakukan.Kebaikan yang kita lakukan dengan mengharapkan untuk mendapatkan pujian dari orang lain disebut dengan riya'. Semoga kita semua dihindarkan dari perasaan riya'.

\section{UCAPAN TERIMA KASIH}

Terima kasih kepada Prof. Zuriyati dan Pak Saifur Rochman yang telah bersabar dalam memberikan ilmu serta mengajarkan sastra.

\section{REFERENSI}

[1] N. Lustyantie, "Pendekatan Semiotika Roland Barthes dalam Karya Sastra Perancis," in Seminar Nasional FIB UI, Depok, 2012.

[2] R. Ida, Metode Penelitian: Studi Media dan Kajian Budaya, Jakarta: Prenada Media Group, 2014.

[3] M. M. Faizetul Ukhrawiyah, "Feminisme dalam Sajak Tkhotibul Mar'ah alMishriyah Karya Bakhisah Al-Badiyah," Diwan, vol. 5, no. 2, 2019.

[4] N. Saptawuryandari, "Analisis Semiotika Roland Barthes dalam Karya Sastra," Kandai, vol. 9, no. 1, 2013.

[5] S. R. Emzir, Teori dan Pengajaran Sastra, Depok: PT. Raja Grafindo Persada, 2017. 